\title{
Phytochemical, in-vitro biological and chemo-preventive profiling of Arisaema jacquemontii Blume tuber extracts
}

Saira Tabassum 1*, Muhammad Zia², Esperanza J. Carcahe de Blanco ${ }^{3}$, Riffat Batool², Roohi Aslam', Sajid Hussain', Qamar Wali ${ }^{1}$ and Muhammad Mudassar Gulzar ${ }^{1}$

\begin{abstract}
Background: Arisaema jacquemontii is traditionally used in treatment of different diseases. In this study, phytochemical, in vitro biological and chemo-preventive screening of A. jacquemontii was carried out to explore its pharmacological potential.

Methods: The dried tuber of A. jacquemontii was extracted in 11 organic solvent mixture of different polarity. The extracts were screened for phytochemical assays (phenolics and flavonoids), antioxidants potential (free radical scavenging activity, total antioxidant activity, reducing power), biological activities (antibacterial, antifungal, cytotoxic, antileishmanial, protein kinase inhibition), and chemopreventive activities using different cell lines through standard protocols.

Results: Significant amount phenolic contents were determined in $\mathrm{EtOH}$ and $\mathrm{MeOH}$ extracts $(210.3 \pm 3.05$ and $193.2 \pm$ $3.15 \mu \mathrm{g} \mathrm{GAE} / \mathrm{mg}$, respectively). Maximum flavonoid content was determined in $\mathrm{MeOH}$ extract $(22.4 \pm 4.04 \mu \mathrm{g} \mathrm{QE} / \mathrm{mg})$. Noteworthy, DPPH scavenging activity was also recorded for MeOH extract (87.66\%) followed by MeOH+EtOAc extract (85.11\%). Considerable antioxidant capacity $(7.8 \pm 0.12 \mu \mathrm{g} \mathrm{AAE} / \mathrm{mg})$ and reducing power $(3.1 \pm 0.15 \mu \mathrm{g} \mathrm{AAE} / \mathrm{mg})$ was observed in extract of $\mathrm{MeOH}$. The $\mathrm{LC}_{50}$ against brine shrimp and leishmanial parasite was found 9.01 and $12.87 \mu \mathrm{g} / \mathrm{mL}$ for $\mathrm{n}-\mathrm{Hex}$ and $\mathrm{CHCl}_{3}$ extracts, respectively. The highest zone of inhibition against Streptomyces hyphae formation $(12.5 \pm 1.77 \mathrm{~mm})$ by $\mathrm{n}$-Hex extract. Growth zone of inhibition $13.8 \pm 1.08 \mathrm{~mm}$ was recorded for EtOAc and $\mathrm{MeOH}$ extracts, respectively against Micrococcus luteus while $10.0 \pm 0.11 \mathrm{~mm}$ for MeOH extract against Aspergillus flavus. In-vitro cytotoxic assay showed that n-Hex extract had higher cytotoxicity against DU-145 prostate cancer and HL-60 cancer cell lines. NF-kB and MTP potential showed 34.01 and $44.87 \mu \mathrm{g} / \mathrm{mL}$ for $\mathrm{n}-\mathrm{Hex}$ and $\mathrm{CHCl}_{3}$ extracts, respectively in chemopreventive potential.
\end{abstract}

Conclusion: The study concludes that Arisaema jacquemontii bears significant phytochemical activity and pharmacological activities, this plant can be further explored for isolation of active component against a number of aliments.

Keywords: Phenolic and flavonoid content, Antioxidant activities, Antimicrobial, SRB cytotoxic assay, NF-kB pathway

\footnotetext{
* Correspondence: sairatabassum@nutech.edu.pk; saira_tabassum@ymail.com ${ }^{1}$ NUTECH School of Applied Sciences and Humanities, National University of Technology (NUTECH), Islamabad, Pakistan

Full list of author information is available at the end of the article
}

(c) The Author(s). 2019 Open Access This article is distributed under the terms of the Creative Commons Attribution 4.0 International License (http://creativecommons.org/licenses/by/4.0/), which permits unrestricted use, distribution, and reproduction in any medium, provided you give appropriate credit to the original author(s) and the source, provide a link to the Creative Commons license, and indicate if changes were made. The Creative Commons Public Domain Dedication waiver (http://creativecommons.org/publicdomain/zero/1.0/) applies to the data made available in this article, unless otherwise stated. 


\section{Background}

The significance of traditional health systems and medicinal plants cannot be denied because nature has placed cure against many diseases in natural materials. Therefore interest towards the herbal medicines and isolation of active compounds is growing incredibly. Medicinal plants are being practiced for different ailments in most of the developing countries. Thousands of plant species have been used for health care purposes in various cultures and derivations of medicinal preparations [1]. A variety of drugs have been isolated from plants, i.e. aspirin from Filipendula ulmavia, benzoin from Slyrax tonkinensis, morphine from Papaver somniferum, quinine from Cinchona pubescens, vincristine and vinblastine from Catharanthus roseus [2]. Despite of the rapid progression toward the field of medicinal chemistry, resistance of microbes against therapeutic agents and enhanced exposure to free radicals necessitate the search of novel therapeutic agents from medicinal plants [3-5].

Arisaema jacquemontii (Araceae) herb (local name "Sap-ki-booti") is freely available in northern region of Pakistan. A. jacquemontii belongs to genus Arisaema which constitutes more than 250 species. It is a deciduous perennial herb that grows to a height of about 1-2 $\mathrm{m} \mathrm{[6]}$ and is further distributed in many parts of East Asia, Afghanistan to South East Tibet, upper and lower alpine zones in the dried areas of Himalayas. Various constituents of this plant, especially tuber lectins are being used for medicinal purposes [7]. A tuber lectin purified from this plant has been reported to exhibit potent anti-insect and anti-proliferative activities [8]. A large number of Arisaema species have been reported as anticonvulsants [9]. The rhizomes or tubers of A. calcareum, A. serratum, $A$. asperatum, $A$. heterophyllum, and $A$. amurense are documented as analgesic, antitumor and pesticidal potential [10]. In addition, secondary metabolites (phenolic acids, flavonoids, anthocyanidins and tannins) isolated from these plants have shown remarkable antioxidant and immunomodulatory activities $[11,12]$. Synergistic effect of drugs and/or herbal extracts can be beneficial or harmful. In case of herbal extracts it depends upon the cumulative effect of active ingredients resulting in similar or related outcomes. For example, vitamin $\mathrm{E}$ is an antioxidant and vitamin $\mathrm{C}$ might help to recycle oxidized vitamin $\mathrm{E}$ into active vitamin E, thus, a synergistic [13]. The different petrochemicals were isolated from the medicinal plants e.g. $\beta$-sitosterol was isolated from medicinal plant having significant potentials against the L. tropica KWH23 by in-vitro anti-promastigotes. $\beta$-sitosterol mediated leishmanicidal potential via apoptosis confirmed by DNA interaction and molecular docking studies [14].

In continuation of efforts to verify the efficiency of medicinal plants with traditional and local knowledge, Arisaema jaquamontii tuber was extracted using polar to non-polar solvents. The extracts were pharmacologically evaluated by using cost effective and highly efficient assays involving antileishmanial, brine shrimp cytotoxicity, SRB cytotoxicity and chemo preventive potential of NF-kB pathway and MTP cycle, protein kinase inhibition, antibacterial and antifungal assays. This study identifies the medicinal potential of A. jaquamontii that will lead towards isolation of active constituents for evaluation in drug usage.

\section{Methods \\ Plant material}

A. jacquemontii was collected in the month of July from Lakary mountains, Shamshaki, District Karak, Khyber Pakhtunkhwa, Pakistan. The plant material was authenticated by Prof Dr. Mir Ajab Khan, Department of Plant Sciences, Quaid-i-Azam University Islamabad, Pakistan. A voucher specimen (PHM: 491) was deposited in the Herbarium of Medicinal Plants, Quaid-i-Azam University Islamabad, Pakistan.

\section{Chemical and reagents}

The study involved the use of analytical grade solvents which were purchased from Sigma (Sigma-Aldrich USA) i.e. n-hexane (n-Hex); Chloroform $\left(\mathrm{CHCl}_{3}\right)$; Acetone (Ace); Ethyl acetate (EtOAc); Ethanol ((EtOH); Methanol $(\mathrm{MeOH})$ and Dimethyl sulfoxide (DMSO). The reagents; Gallic acid (G7385); Quercetin (Q4951); 2,2-diphenyl-1picryl-hydrazyl (Cat\#757621; DPPH); Potassium acetate; Aluminum Chloride; Folin-ciocaltau (F-C) reagent -Sodium carbonate; Ascorbic acid (A5960); Ammonium molybdate; Sodium phosphate; Sulfuric acid; Ferric cyanide; Trichloroacetic acid and Potassium ferricyanide were procured from Merck (Merck KGaA, Germany). Roxithromycin (R4393); Cefixime (1097658); Terbinafine (T8826), Doxorubicin (D1515), Taxol (T1912) and Amphotericin-B (A2942) was obtained from Sigma (Sigma-Aldrich USA) were used Reference standards in the current study.

\section{Preparation of extracts}

Tubers of $A$. jacquemontii were washed with tap water then rinsed with distilled water. The material was air dried under shade at room temperature. After comminuting the plant material by using the commercial miller to coarse powder, $10 \mathrm{~g}$ of dried powder material was soaked separately in beakers, each containing $40 \mathrm{~mL}$ of extraction solvents of ranging polarity from highly non-polar to highly polar solvents including $n$-hexane (n-Hex), Chloroform $\left(\mathrm{CHCl}_{3}\right)$, Acetone (Ace), Ethyl acetate (EtOAc), Ethanol (EtOH), Methanol (MeOH). Along with individual solvents, combinations of solvents at 1:1 were also used as follow: $\mathrm{EtOH}+\mathrm{CHCl}_{3}, \mathrm{MeOH}+\mathrm{CHCl}_{3}$, Ace+EtOAc, $\mathrm{EtOH}+\mathrm{EtOAc}$, and $\mathrm{MeOH}+\mathrm{EtOAc}$. The plant material was soaked for $48 \mathrm{~h}$, thereafter filtered through 
Whatman No.1 filter paper. The residue was again dipped in respective solvent/s and this process was repeated thrice. The respective extracts were combined and concentrated by evaporating the solvent under reduced pressure in a rotary evaporator (Buchi, Switzerland) at $45^{\circ} \mathrm{C}$.

\section{Phytochemical screening Determination of total phenolic contents}

The total phenolic contents of the extracts were determined by Folin-Ciocalteu method [15]. Briefly, stock solutions of extracts $(4 \mathrm{mg} / \mathrm{mL})$ were prepared in DMSO and $20 \mu \mathrm{L}$ of each extract was transferred to each well of 96 well plate. The solutions were then mixed with $90 \mu \mathrm{L}$ of F-C (Folin-Ciocalteu) reagent. After $5 \mathrm{~min}$, the reaction mixture was mixed with $90 \mu \mathrm{L}$ of $\mathrm{Na}_{2} \mathrm{CO}_{3}$ solution (7.5\%). The reaction mixture was incubated for $1 \mathrm{~h}$ and absorbance was measured at $650 \mathrm{~nm}$ by using microplate reader (Bioteck). Blank (DMSO) and standard (gallic acid in DMSO) were run simultaneously. The resultant TPC is calculated as $\mu \mathrm{g}$ gallic acid equivalents per $\mathrm{mg}$ extract ( $\mu \mathrm{g} \mathrm{GAE} / \mathrm{mg}$ extract).

\section{Determination total flavonoid content (TFC)}

The TFC of the extracts was determined by aluminum chloride method as reported previously [15]. Briefly, extract solution $(20 \mu \mathrm{L}, 4 \mathrm{mg} / \mathrm{mL}$ DMSO) was mixed with $10 \mu \mathrm{L}$ of aluminum chloride $(10 \%)$ and $10 \mu \mathrm{L}$ of potassium acetate $(1 \mathrm{M})$. Subsequently, distilled water was added to get a final volume of $200 \mu \mathrm{L}$. After $30 \mathrm{~min}$ of incubation (Incubator IC83 Yomato, Japan), absorbance was measured by using microplate reader (Bioteck) at $415 \mathrm{~nm}$ at $37^{\circ} \mathrm{C}$. Quercetin was used as standard flavonoid and results are expressed as $\mu \mathrm{g}$ quercetin equivalent per mg extract ( $\mu \mathrm{g} \mathrm{QE} / \mathrm{mg}$ extract).

\section{Biological evaluation DPPH free radical scavenging assay}

2, 2-diphenyl-1-picrylhydrazyl reagent was employed for the determination of free radical scavenging activity of the extracts [15]. Briefly, stock solutions of extracts $(4 \mathrm{mg} / \mathrm{mL})$ were prepared in DMSO. Aliquot of $10 \mu \mathrm{L}$ of each extract was mixed with $190 \mu \mathrm{L}$ of DPPH (0.004\%). The reaction mixture was incubated in the dark for $1 \mathrm{~h}$. The optical density was measured at $515 \mathrm{~nm}$ using microplate reader (Bioteck). Ascorbic acid was employed as positive standard while DMSO as negative control. The extracts were first screened at final concentration of $200 \mu \mathrm{g} / \mathrm{mL}$ and those exhibiting good quenching activity $\left(\geq 50 \%\right.$ ) were tested at lower concentration to find $\mathrm{IC}_{50}$ values. Percent inhibition was calculated by the following formula:

$$
\begin{aligned}
& \text { Percent inhibition of the test sample } \\
& \quad=\left[\% \text { scavenging activity }=\left(\mathbf{1}-\mathbf{A} \mathbf{b}_{\mathbf{s}} / \mathbf{A} \mathbf{b}_{\mathbf{c}}\right) * \mathbf{1 0 0}\right]
\end{aligned}
$$

Where $A b_{s}$ is the absorbance of DPPH solution with sample, whereas $\mathrm{Ab}_{\mathrm{c}}$ indicates the absorbance of negative control (containing the reagent except the sample). The $\mathrm{IC}_{50}$ was calculated by using Table curve software $2 \mathrm{D}$ version 4 .

\section{Determination of total antioxidant capacity (TAC)}

Total antioxidant activity of extracts was evaluated following the methodology previously reported [15] Mixing $100 \mu \mathrm{L}$ of stock solution of each extract $(4 \mathrm{mg}$ / $\mathrm{mL}$ in DMSO) with $900 \mu \mathrm{L}$ reagent solutions comprising of $0.6 \mathrm{M}$ sulfuric acid, $4 \mathrm{mM}$ ammonium molybdate and $28 \mathrm{mM}$ sodium phosphate was done. The reaction mixtures were incubated at $95^{\circ} \mathrm{C}$ for $90 \mathrm{~min}$. After incubation the reaction mixtures were cooled down at room temperature and absorbance of each extract was measured at $695 \mathrm{~nm}$ by using micro plate reader. A typical blank containing DMSO $(100 \mu \mathrm{L})$ was used as control. For the calibration curve, ascorbic acid was used at different concentrations with DMSO. The resultant TAC is expressed as $\mu \mathrm{g}$ ascorbic acid equivalent per $\mathrm{mg}$ extract ( $\mu \mathrm{g} \mathrm{AAE} / \mathrm{mg}$ extract).

\section{Reducing power assay}

The reduction potential of the test samples were investigated according to the procedure described previously [15]. Briefly, $100 \mu \mathrm{L}$ of each sample $(4 \mathrm{mg} / \mathrm{mL}$ extract in DMSO) was mixed with $200 \mu \mathrm{L}$ of phosphate buffer $(0.2$ $\mathrm{M}, \mathrm{pH} 6.6)$ and $250 \mu \mathrm{L}$ of $1 \%$ potassium ferricyanide solution. The resulting mixtures were incubated for $20 \mathrm{~min}$ at $50{ }^{\circ} \mathrm{C}$. After incubation, the reaction mixtures were acidified with $200 \mu \mathrm{L}$ of $10 \%$ trichloroacetic acid. The resultant mixtures were centrifuged at $3000 \mathrm{rpm}$ for $10 \mathrm{~min}$. Supernatant layer $(150 \mu \mathrm{L})$ was mixed with $50 \mu \mathrm{L}$ of $0.1 \%$ ferric chloride solution in a separate tube and optical density was measured at $630 \mathrm{~nm}$ using microplate reader. Ascorbic acid was maintained as positive control and results are expressed as $\mu \mathrm{g}$ ascorbic acid equivalent per mg extract ( $\mu \mathrm{g} \mathrm{AAE} / \mathrm{mg}$ extract).

\section{Brine shrimp lethality assay}

The degree of lethality to brine shrimps was determined by following previously described protocol [16]. Stock solutions $(100 \mathrm{mg} / \mathrm{mL})$ of each sample were prepared in DMSO. Artemia salina (brine shrimp) eggs (Ocean Star, USA) were hatched in a bi-partitioned tank filled with artificial sea water $(3.8 \%$ Sea salt supplemented with $6 \mathrm{mg} / \mathrm{mL}$ dried yeast, $\mathrm{pH} 7$ ). The larger compartment was covered with aluminum foil while the smaller compartment was illuminated with a light source. After 24-48 h incubation period the phototropic nauplii were 
harvested by using micro pipette and transferred to 96 well plate. Various sub dilutions of $100 \mathrm{mg} / \mathrm{mL}$ DMSO stock solution of each extract were tested for lethality determination at final concentrations of 250, 125, and $62.5 \mu \mathrm{g} / \mathrm{mL}$. The corresponding micro liter of each dilution was transferred to each well containing 10 nauplii and $300 \mu \mathrm{L}$ sea water supplemented with dried yeast $(6 \mathrm{mg} / \mathrm{L})$. Negative control vial included DMSO, nauplii and sea water, but no sample, whereas positive control included $4 \mathrm{mg} / \mathrm{ml}$ standard drug doxorubicin, nauplii and sea water. After $24 \mathrm{~h}$ incubation period, dead nauplii were counted in each vial and $\mathrm{LC}_{50}$ was measured accordingly by comparing percentage mortality with standard drug using Table curve software $2 \mathrm{D}$ version 4.

\section{Protein kinase inhibition assay}

Streptomyces 85E strain was used for protein kinase inhibition assays following the published protocol [17]. The microorganism was refreshed in sterile Trypton Soy broth (Merck, Germany) for 24-48 h. The cultured was inoculated ISP4 mineral medium in petri plates. $5 \mathrm{~mm}$ Whattman filter paper discs impregnated with $5 \mu \mathrm{L}$ of $20 \mathrm{mg} / \mathrm{mL}$ extracts were placed on seeded plates. The plates were incubated at $28^{\circ} \mathrm{C}$ for $72 \mathrm{~h}$. The bald zones of hyphae formation inhibition were measured. Surfactin was used as positive control while DMSO impregnated discs were included as negative control in order to confirm the non toxic effect of DMSO.

\section{In vitro antileishmanial activity}

In vitro antileishmanial activity was performed with Leishmania tropica khw23 strain [18]. The Leishmanial parasite was kindly provided by Dr. Gul Shahnaz and protocol was followed as described [18]. The parasite was cultured in M199 media supplemented with 10\% Fetal Bovine Serum at $24{ }^{\circ} \mathrm{C}$.The culture (promastigotes) was harvested at concentration of $1 \times 10^{6}$ cells $/ \mathrm{mL}$. Stock solution of each test samples was prepared in DMSO $(20 \mathrm{mg} / \mathrm{mL})$ and serially diluted in 96 well plate. The anti leishmanial activity of each sample was determined at concentrations ranging from $62.5-250 \mu \mathrm{g} / \mathrm{mL}$. The cultured plates, inoculated with parasite and test samples, were incubated at $24{ }^{\circ} \mathrm{C}$ for $72 \mathrm{~h}$. Amphotericin-B was employed as positive control while distilled water as a negative control. The live promastigotes were counted under light microscope using improved Neubauer chamber. The data obtained was then statistically analyzed and $\mathrm{LC}_{50}$ was estimated using table curve 2D Ver.4 software.

\section{Antibacterial activity}

Antibacterial assay was performed against five bacterial strains (two Gram positive (Micrococcus luteus ATCC\#
10240 and Staphylococcus aureus ATCC\# 6538) and three Gram negative (Bordetella bronchiseptica ATCC\# 4617, Salmonella typhimurium ATCC\# 14028 and Enterobacter aerogenes ATCC\# 13048) following the standard protocol [15]. The strains were purchased from ATCC culture bank and maintained in the lab. The strains were recultured by inoculating them from stored slants onto nutrient broth media and incubated for 18 $24 \mathrm{~h}$. The refreshed inoculum was then swabbed onto petri plates filled with nutrient agar. Sterilized deionized water was used to adjust the turbidity to $10^{4} \mathrm{CFU} / \mathrm{mL}$ by comparing with McFarland $0.5 \mathrm{BaSO}_{4}$ turbidity standard. The extract ( $5 \mu \mathrm{L}$ of $20 \mathrm{mg} / \mathrm{ml}$ DMSO) infused filter paper discs $(6 \mathrm{~mm})$ were placed on swabbed nutrient agar plate. Roxithromycin $(4 \mathrm{mg} / \mathrm{ml})$, Cefixime-USP $(4 \mathrm{mg} / \mathrm{ml})$ and DMSO impregnated discs were included as positive and negative control, respectively. After $24 \mathrm{~h}$ incubation period, clear zone of growth inhibition around sample and standard treated discs was measured by using vernier caliper. The samples having $\geq 11.0 \mathrm{~mm}$ zone of inhibition were tested at lower concentrations (100-50 and $25 \mu \mathrm{g} / \mathrm{ml}$ ) by using microtiter plate broth dilution method to find minimum inhibitory concentration (MIC).

\section{Antifungal activity}

Antifungal activity of each sample was evaluated following the method described previously [17]. The fungal strains were kindly provided by First Culture Bank of Pakistan Punjab University Lahore Pakistan. Fungal cultures (Aspergillus fumigatus FCBP\# 66, Fusarium solani FCBP\# 0291, Mucor specie FCBP\# 0300, Aspergillus flavus FCBP\# 0064 and Aspergillus niger FCBP\# 0198) were cultured on Sabouraud Dextrose Agar medium (SDA; Merck Germany). Prior to the sensitivity determination, the spores of fungal strains were harvested in $0.02 \%$ between 20 solution and their turbidity was adjusted according to McFarland 0.5 turbidity standard. Then $100 \mu \mathrm{L}$ of each harvested spores was swabbed on plates containing SDA. Filter paper discs loaded with $5 \mu \mathrm{L}$ of extract $(20 \mathrm{mg} / \mathrm{ml}$ in DMSO) as well as $2.5 \mu \mathrm{L}$ of standard antifungal terbinafine $(4 \mathrm{mg} / \mathrm{ml})$ were placed on swabbed SDA plates. The plates were incubated at $28^{\circ} \mathrm{C}$ for $24 \mathrm{~h}$. After that the clear zones of growth inhibition around sample infused discs were measured using vernier caliper.

\section{SRB cytotoxic assay against DU-145, HL-60 cancer cell lines}

The cytotoxic potential of test samples to adherent cancer cell lines was determined by using SRB colorimetric assay [17]. All the cell lines were cultured in DMEM medium except for HL-60 that was cultured in RPMI1640. Basic media were supplemented with $5 \% \mathrm{FBS}$ and $1 \%$ antibody $(\mathrm{AB})$ solution and maintained at $37^{\circ} \mathrm{C}$ in $5 \% \mathrm{CO}_{2}$ incubator to achieve the desired level of 
confluence. For adherent cells, after removing the old medium, cells were washed thrice with PBS and $1 \mathrm{~mL}$ of trypsin was added and put in the incubator for $5 \mathrm{~min}$. Cells with trypsin were shaken along with $5 \mathrm{~mL}$ of fresh medium and transferred a falcon tube. For suspended cultures, cells were transferred to falcon tube and centrifuged for $5 \mathrm{~min}$ at $1500 \mathrm{rpm}$. Old medium was then replaced with $5 \mathrm{~mL}$ fresh medium. Cells were counted using Hemocytometer and seeding density was adjusted to $5 \times 10^{4}$ cells $/ \mathrm{mL}$.

During assay, $10 \mu \mathrm{L}$ of extract was thoroughly mixed with $190 \mu \mathrm{L}$ of culture in 96-well plate and incubated for $72 \mathrm{~h}$ at $33^{\circ} \mathrm{C}$. Then, $100 \mu \mathrm{L}$ of $20 \% \mathrm{w} / \mathrm{v}$ TCA was added and incubated for $30 \mathrm{~min}$ at $4{ }^{\circ} \mathrm{C}$ to fix the cells. It was then washed three times with water, air dried and incubated with $100 \mu \mathrm{L}$ of $0.4 \% \mathrm{w} / \mathrm{v}$ SRB in $1 \%$ acetic acid for $30 \mathrm{~min}$ at room temperature. Afterwards, wells were washed with $1 \%$ acetic acid, air dried and exposed to $200 \mu \mathrm{L}$ of $10 \mathrm{mM}$ Tris base for $5 \mathrm{~min}$ in the plate shaker. Absorbance of the microplate was measured at $492 \mathrm{~nm}$ using the plate reader. Taxol $(400 \mu \mathrm{g} / \mathrm{mL})$ was used as positive control while culture media having no visible growth was used as blank. 10\% DMSO PBS used was negative control.

\section{Cancer chemo preventive bioassays \\ Inhibition of TNF-a activated nuclear factor-kappa B (NF- кB) assay}

The NF- $\mathrm{kB}$ assay was carried out in accordance to a previously published protocol [17]. In brief, the Hela cells nuclear extract was treated with each extract and TNF- $\alpha$ was used for evaluation for specific binding. After treatment with test samples, cells were treated with TNF- $\alpha(10 \mathrm{ng} / \mathrm{mL})$ and the nuclear extract from the cells extracted using NE-PER ${ }^{\mathrm{Tu}}$ Nuclear and Cytoplasmic Extraction Reagents kit from Thermo Scientific (Pierce Biotechnology, Rockford, IL, USA). The specific binding ability of activated NF-kB p65 to the biotinylated-consensus sequence under the presence of test samples was assessed using the Pierce ${ }^{\mathrm{rm}}$ NF- $\mathrm{kB}$ p65 Transcription Factor Assay kit from Thermo Scientific (Pierce Biotechnology, Rockford, IL, USA). The binding activity was measured by detecting the chemiluminescent signal in a Fluostar Optima plate reader. The test samples exhibiting over $50 \%$ inhibition at $50 \mu \mathrm{g} / \mathrm{mL}$ were also tested at four concentration levels $(0.05 \mu \mathrm{g} / \mathrm{mL}-$ $50 \mu \mathrm{g} / \mathrm{mL}$ ), to obtain inhibitory concentration $\left(\mathrm{IC}_{50}\right)$. Rocaglamide was used as a positive control and untreated cells as negative control.

\section{Mitochondria transmembrane potential (MTP) assay}

Variations on the mitochondria trans-membrane potential were noticed and measured by a fluorescence cell based assay as described previously [17]. In short, cells were cultured in black and clear bottom plates of 96well plates at a density of $6 \times 10^{4}$ cells $/ \mathrm{mL}$ and incubated for $24 \mathrm{~h}$ at $37^{\circ} \mathrm{C}$ in a humified $5 \% \mathrm{CO}_{2}$ incubator. Cells were then treated with the test samples and staurosporine (positive control) for $2 \mathrm{~h}$. The cells were incubated with the lipophilic cationic dye $\left(5,5^{\prime}, 6,6^{\prime}\right.$-tetrachloro$1,1^{\prime}, 3,3$ '-tetraethyl benzymidazolyl carbocyanide) JC-1 for $30 \mathrm{~min}$. After incubation, cells were washed with a buffer for removing unbound staining reagent. The clear bottom plates were then scanned with fluorescence imaging microscope. Black 96-well plates were analyzed by a plate reader (FLUO-star-Optima-fluorescence) with excitation and emission wavelengths of $485 \mathrm{~nm}$ and $530 \mathrm{~nm}$ respectively for JC-1 monomers while excitation and emission wavelengths of $560 \mathrm{~nm}$ and $595 \mathrm{~nm}$ respectively for J-aggregates. Measurements were performed in triplicate and are representative of at least two independent experiments.

\section{Statistical analysis}

The data is presented as mean \pm standard deviation (SD). All the experiments were carried out in triplicate. SPSS Ver. 21 software was used for Post Hoc Multiple Comparison test in One Way ANOVA and $\mathrm{IC}_{50}$ was determined by using Table curve software $2 \mathrm{D}$ version 4 . Origin 8.5 software was used for graphical presentation.

\section{Results}

Total 11 extracts of $A$. jaquamontii tubers were prepared in different solvents and used for determination of pharmacological potential. The percentage yield of extracts along with sample codes is described in Table 1. Maximum extraction yield was obtained with the $\mathrm{MeOH}$ followed by $\mathrm{MeOH}+\mathrm{CHCl}_{3}$ and $\mathrm{EtOH}$. Extract of n-Hex was obtained in minimum quantity.

Table 1 A. jacquemontii extraction in different organic non polar to polar solvent with percent yield

\begin{tabular}{llll}
\hline S/ No. & Sample code & Solvent & \% Yield (g) \\
\hline 1 & n-Hex & n-hexane & 0.289 \\
2 & $\mathrm{CHCl}_{3}$ & Chloroform & 0.55 \\
3 & Ace & Acetone & 0.321 \\
4 & $\mathrm{EtOAc}$ & Ethyle acetate & 0.765 \\
5 & $\mathrm{EtOH}$ & Ethanol & 6.68 \\
6 & $\mathrm{MeOH}$ & Methanol & 8.753 \\
7 & $\mathrm{EtOH}+\mathrm{CHCl}_{3}$ & Ethanol+Chloroform & 2.75 \\
8 & $\mathrm{MeOH}+\mathrm{CHCl}_{3}$ & Methanol+Chloroform & 7.159 \\
9 & $\mathrm{Ace}+\mathrm{EtOAc}$ & Acetone+Ethyl acetate & 0.589 \\
10 & $\mathrm{EtOH}+\mathrm{EtOAc}$ & Ethanol+Ethyl acetate & 1.016 \\
11 & $\mathrm{MeOH}+\mathrm{EtOAc}$ & Methanol+Ethyl acetate & 0.975 \\
\hline
\end{tabular}




\section{Phytochemical evaluation}

Among all extracts, the highest amount of gallic acid equivalent TPC was determined in $\mathrm{EtOH}$ (210.66 \pm $4.04 \mu \mathrm{g} / \mathrm{mg})$ and $\mathrm{MeOH}$ extract $(193.33 \pm 5.40 \mu \mathrm{g} / \mathrm{mg})$ followed by $\mathrm{MeOH}+\mathrm{CHCl}_{3}(169.66 \pm 4.50 \mu \mathrm{g} / \mathrm{mg})$. The lowest value of TPC was determined in n-Hex extract $(6.23 \pm 1.40 \mu \mathrm{g} \mathrm{GAE} / \mathrm{mg})$ as shown in Fig. 1. The quercetin equivalent total flavonoid content was found varying between $11.29-22.33 \mu \mathrm{g} / \mathrm{mg}$. The highest content was observed in $\mathrm{MeOH}(22.33 \pm 3.05 \mu \mathrm{g} / \mathrm{mg})$, $\mathrm{EtOH}(20.62 \pm 3.15 \mu \mathrm{g} / \mathrm{mg})$ and $\mathrm{MeOH}+\mathrm{CHCl}_{3}$ extract $(18.30 \pm 2.51 \mu \mathrm{g} / \mathrm{mg}$ ) (Fig. 1).

\section{Biological evaluation}

The free radical quenching results are summarized in Fig. 1. The DPPH scavenging potential of extracts ranged from 21.61 to $87.66 \%$. Significant activity $(p<$ $0.05)$ was observed for $\mathrm{MeOH}\left(87.66 \%: \mathrm{IC}_{50}=45 \mu \mathrm{g} / \mathrm{ml}\right)$, $\mathrm{MeOH}+\mathrm{EtOAc}$ (85.03\%: $\left.\mathrm{IC}_{50}=76 \mu \mathrm{g} / \mathrm{ml}\right)$ and $\mathrm{EtOH}$ extract $\left(83.11 \%: \mathrm{IC}_{50}=32 \mu \mathrm{g} / \mathrm{ml}\right)$. The lowest scavenging activity was found in $\mathrm{n}$-Hex extract with only $12 \%$ free radical scavenging potential. The highest antioxidant capacity, expressed as equivalent of ascorbic acid, was observed for $\mathrm{MeOH}(7.86 \pm 0.12 \mu \mathrm{g} \mathrm{AAE} / \mathrm{mg})$ followed by $\mathrm{EtOH}(7.3 \pm 0.15 \mu \mathrm{g} \mathrm{AAE} / \mathrm{mg}), \mathrm{EtOH}+\mathrm{CHCl}_{3}(6.7 \pm$ $0.22 \mu \mathrm{g} \quad \mathrm{AAE} / \mathrm{mg})$ and $\mathrm{MeOH}+\mathrm{EtOAc}(4.45 \pm 0.20 \mu \mathrm{g}$ $\mathrm{AAE} / \mathrm{mg})$. The lowest TAC was manifested by $\mathrm{n}-\mathrm{Hex}$ extract $(0.36 \pm 0.20 \mu \mathrm{g} \mathrm{AAE} / \mathrm{mg})$. The color of the reaction mixture changes either to green or blue depending on the reducing power of the extracts. A high absorbance confirmed higher reducing power. Among all samples,
$\mathrm{MeOH}$ and $\mathrm{EtOH}$ extracts exhibited highest reduction potential i.e. $3.1 \pm 0.14$ and $3 \pm 0.15 \mu \mathrm{g} \mathrm{AAE} / \mathrm{mg}$, respectively (Fig. 1). The least possible reducing power was exhibited by $n-H e x$ extract $(0.06 \pm 0.057 \mu \mathrm{g}$ AAE $/ \mathrm{mg})$.

\section{Cytotoxicity assay}

The percentage mortality/cytotoxicity of the extracts is shown in Fig. 2. $\mathrm{LC}_{50}$ values calculated for each extract against brine shrimps ranged from 9 to $18 \mu \mathrm{g} / \mathrm{mL}$ with highly potent cytotoxicity exhibited by $\mathrm{n}-\mathrm{Hex}\left(80 \% ; \mathrm{LC}_{50}=\right.$ $9.01 \mu \mathrm{g} / \mathrm{mL})$ and $\mathrm{EtOH}\left(67 \% ; \mathrm{LC}_{50}=13.24 \mu \mathrm{g} / \mathrm{mL}\right), \mathrm{MeOH}$ extracts $\left(75 \% ; \mathrm{LC}_{50}=14 \mu \mathrm{g} / \mathrm{mL}\right)$ and $\mathrm{EtOH}+\mathrm{EtOAc}(60 \%$; $\left.\mathrm{LC}_{50}=14.11 \mu \mathrm{g} / \mathrm{mL}\right)$. Protein kinase inhibitory activity of different solvent extracts was evaluated against Streptomyces strain. All samples exhibited significant kinase inhibition potential. Highly significant activity $(p<0.05)$ was recorded for $n$-Hex extract with $12.5 \pm 1.77 \mathrm{~mm}$ bald zone of hyphae formation inhibition (Fig. 3).

In vitro anti-leishmanial activity of different solvent extracts was studied against L. tropica strain (kwh23). The percent mortality of the L. tropica is depicted in Fig. 4. The results reveal that all the plant extracts exhibited significant anti-leishmanial activity with $100 \%$ mortality at highest concentration $(250 \mu \mathrm{g} / \mathrm{mL})$, except for $\mathrm{EtOH}$ extract $(76.33 \%)$. As the concentration decreased, the percent mortality reduced. At concentration $125 \mu \mathrm{g} / \mathrm{mL}$, the highest activity was observed for $\mathrm{CHCl}_{3}$ extract $\left(82.33 \% ; \quad \mathrm{LC}_{50}=12.87 \mu \mathrm{g} / \mathrm{mL}\right), \quad \mathrm{MeOH}$ extract $\left(78 \% \mathrm{LC}_{50}=13.47 \mu \mathrm{g} / \mathrm{mL}\right)$ and Ace extract $(74 \%$; $\left.\mathrm{LC}_{50}=14.13 \mu \mathrm{g} / \mathrm{mL}\right)$.

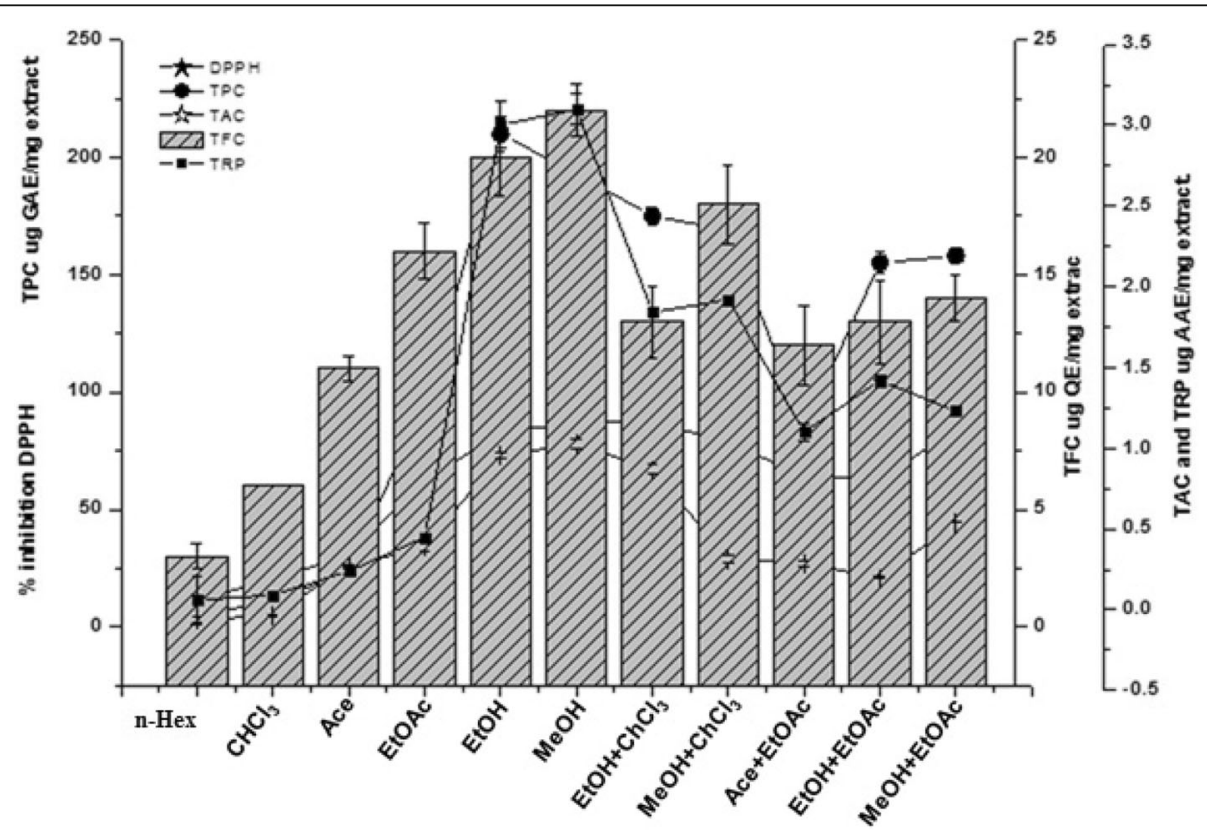

Fig. 1 Total phenolic, flavonoid contents and antioxidant activity of different non polar to polar solvent extracts of A. jacquemontii 


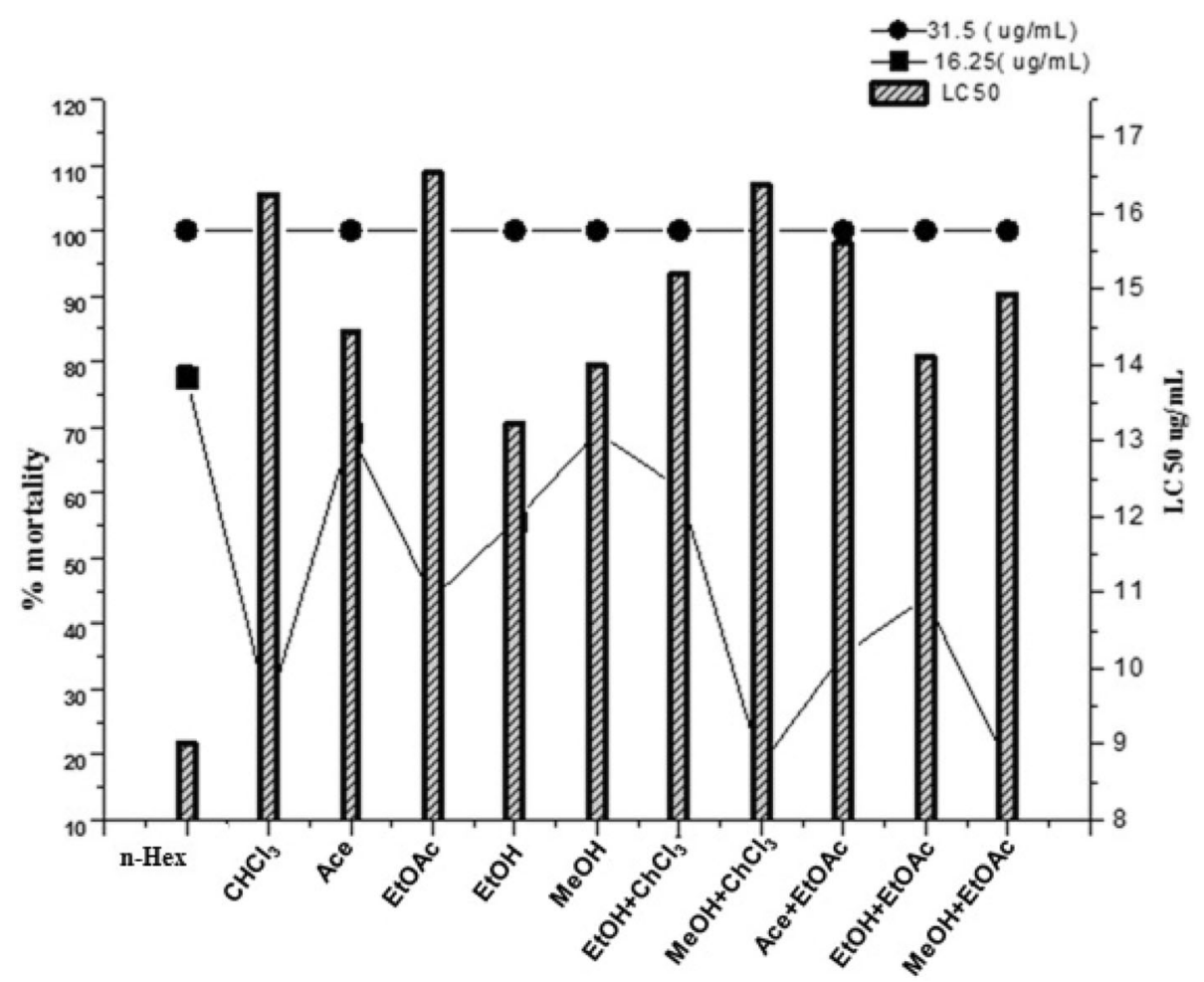

Fig. 2 Percent mortality with corresponding $L C_{50}(\mu \mathrm{g} / \mathrm{ml})$ of different non polar to polar solvent extracts of $A$. jacquemontii against brine shrimps larvae

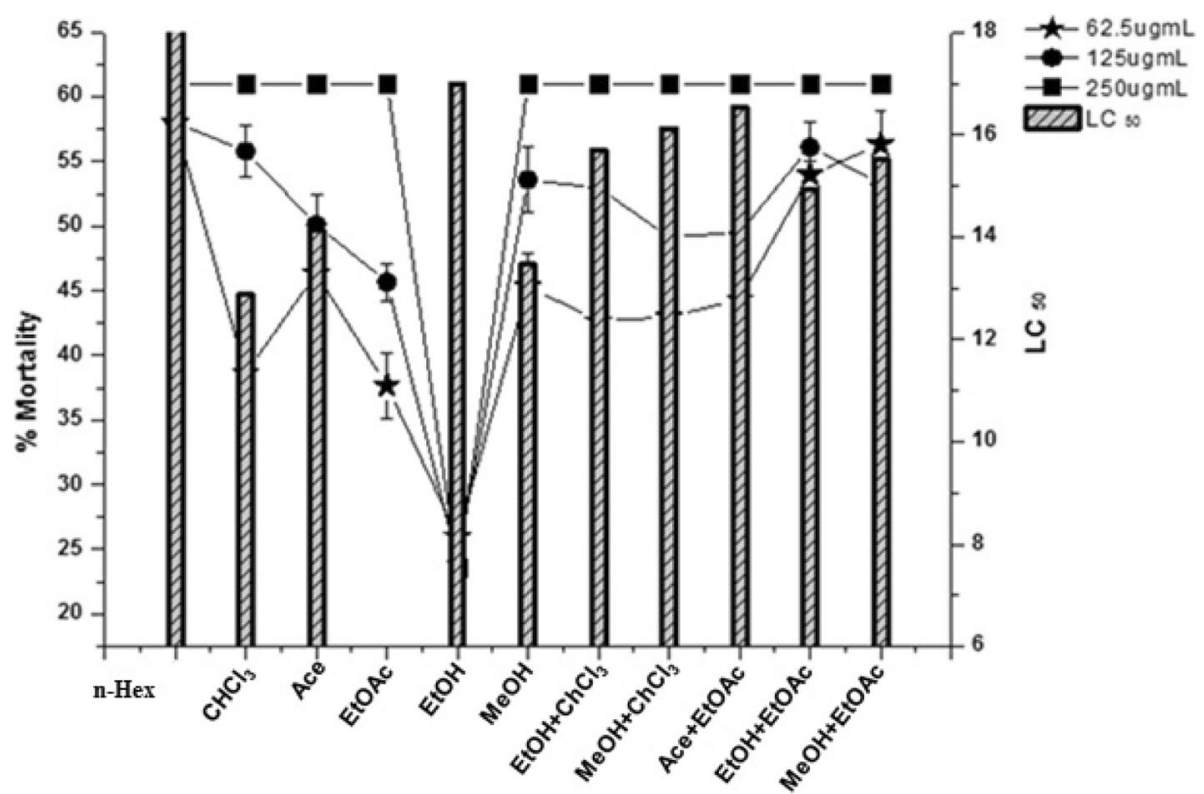

Fig. 3 Protein kinase inhibition potential of A. jacquemontii extracts. Values are presented as Mean + SD, LSD test for pair wise comparison, not significantly different $(P>0.05)$. GOl of standard Surfactin comes out to be $17 \pm 1.2 \mathrm{~mm}$ 


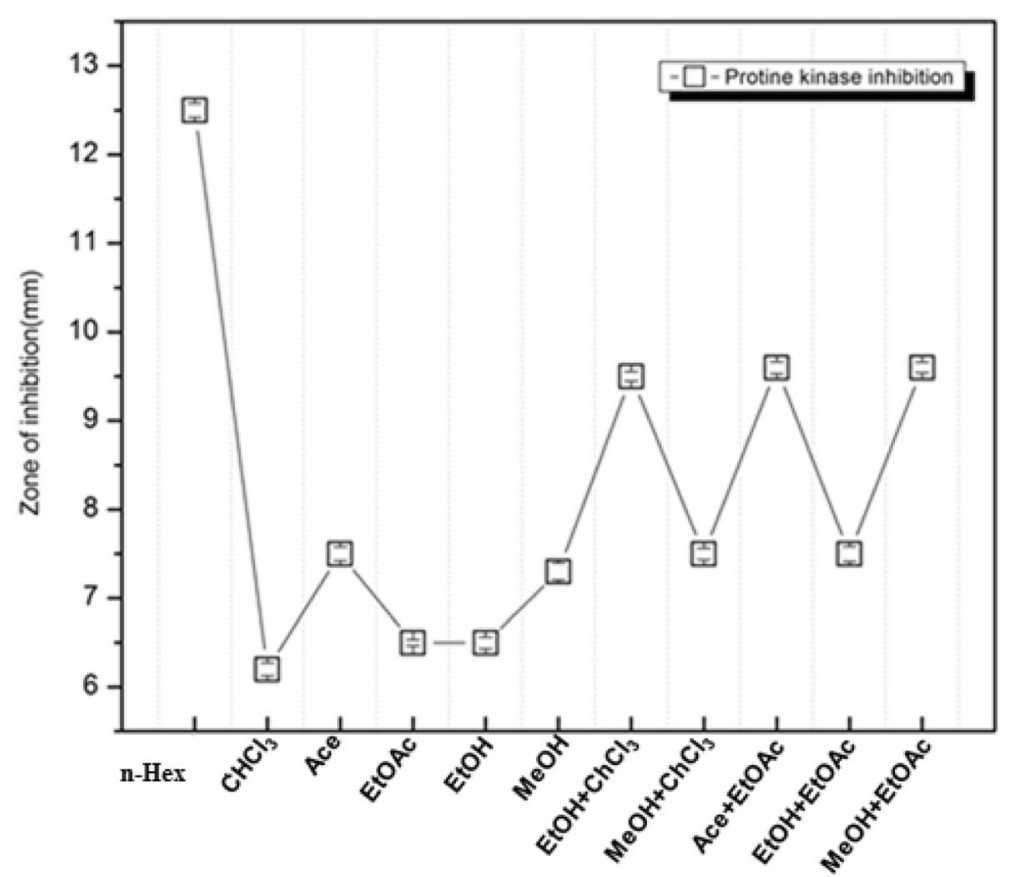

Fig. 4 Percent mortality $\left(\mathrm{LC}_{50} \mu \mathrm{g} / \mathrm{ml}\right)$ exhibited by different solvent extracts against $L$. tropica

\section{Antimicrobial activity}

The sensitivity of each test sample was evaluated against bacterial and fungal strains by disc diffusion method. $\mathrm{EtOH}$ and $\mathrm{MeOH}$ extracts exhibited highest activity against $M$. luteus with $13.8 \pm 1.08 \mathrm{~mm}$ zone of inhibition (MIC: $50 \mu \mathrm{g} / \mathrm{ml}$ ) and $13 \pm 0.15 \mathrm{~mm}$ zone (MIC: $50 \mu \mathrm{g} / \mathrm{ml}$ ) followed by $\mathrm{MeOH}$ and Ace+EtOAc with $11.7 \pm 1.42$ (MIC: $75 \mu \mathrm{g} / \mathrm{ml}$ ) and $11 \pm 0.51 \mathrm{~mm}$ (MIC: $75 \mu \mathrm{g} / \mathrm{ml}$ ) zone of growth inhibition against $B$. septic, respectively (Table 2 and Fig. 5). From the susceptibility results against fungal strains, $\mathrm{MeOH}$ extract exhibited highest sensitivity against $F$. flavusand $M$. speciewith $10.0 \pm 0.11 \mathrm{~mm}$ and $9.7 \pm 0.41 \mathrm{~mm}$ growth inhibition zones, respectively. While $\mathrm{MeOH}+\mathrm{ChCl}_{3}$ exhibited $9.8 \pm 0.71 \mathrm{~mm}$ growth inhibition zone against F. solani followed by $\mathrm{MeOH}$ extract with $9.5 \pm 0.11 \mathrm{~mm}$ inhibition zone (Table 3 and Fig. 6).

\section{SRB cytotoxic activity against DU-145, \& HL-60}

The cytotoxic potential of $A$. jaquamontii tuber extract against the cancer cell lines is presented in Table 4 . The heights cytotoxity showed by the n-Hex extract against the DU-145 prostate cancer cell line the $E_{50}$ as $(45.11 \mu \mathrm{g} / \mathrm{mL})$. EtOAc and $\mathrm{MeOH}$ extracts also showed good cytotoxity against the DU-145 with $\mathrm{ED}_{50}$ valve $52.2 \mu \mathrm{g} / \mathrm{mL}$ and $66.2 \mu \mathrm{g} / \mathrm{mL}$, respectively. According to the HL-60 human leukemia cancer cell lines the $\mathrm{ED}_{50}$ valve of $\mathrm{n}$-hex extract was $55.2 \mu \mathrm{g} / \mathrm{mL}$ followed by $\mathrm{MeOH}$ extract $\left(\mathrm{ED}_{50} 66.2 \mu \mathrm{g} / \mathrm{mL}\right)$. The $\mathrm{n}-\mathrm{Hex}$ and $\mathrm{ChCl}_{3}$ extracts was found to be $34.01 \mu \mathrm{g} / \mathrm{mL}$ and $44.87 \mu \mathrm{g} / \mathrm{mL}$, respectively in chemo-preventive bioassay by NF-kB and MTP potential.

\section{Discussion}

Phytochemicals participate actively in the treatment of various ailments and are considered as significant part of both traditional and modern system of medicines. Polarity dependent extract efficiency variation was observed which signifies the impact of solvent nature on extraction of phytochemicals. The polar solvents tended to extract at higher rate probably due to the presence of polar phytochemicals that are radically available in the water environment (the most powerful polar solvent). It has also been postulated that highly delocalized electrons make most of the plant components highly polarized [19].

Phenols are the compounds that bear a hydroxyl group on its aromatic hydrocarbon ring. The recognition of high concentration of phenolic and flavonoid contents in EtOH and $\mathrm{MeOH}$ extracts, respectively of A. jaquamontii clues that this plant has significant antioxidative potential. Polar solvents showed better recovery of phenolics and flavonoids due to their ionic nature that support solubility of phenolics and flavonoids. Phenolic compounds are major component of non-enzymatic antioxidant defense system of the cell. This property is due to unique structure of phenols and flavonoids that support them to sequent free radicals [20]. Phenolic compounds also possess multiple biological significance such as antitumor, antimutagenic and antibacterial 


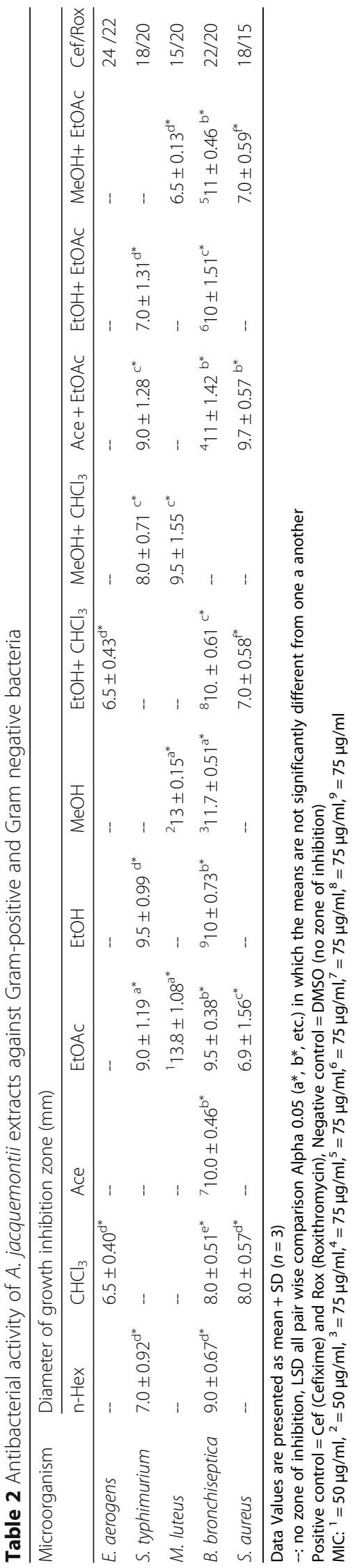


(a)
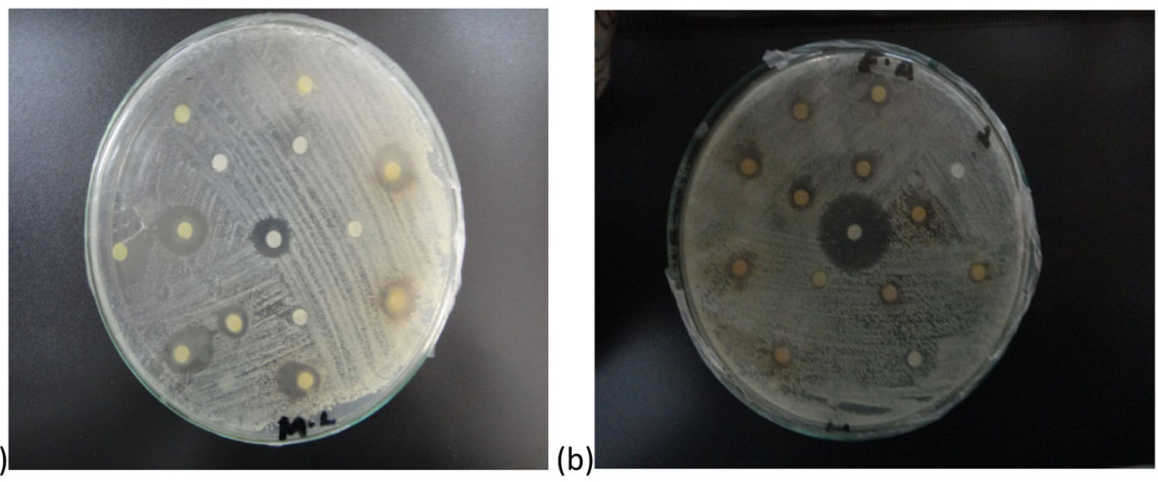

(c)
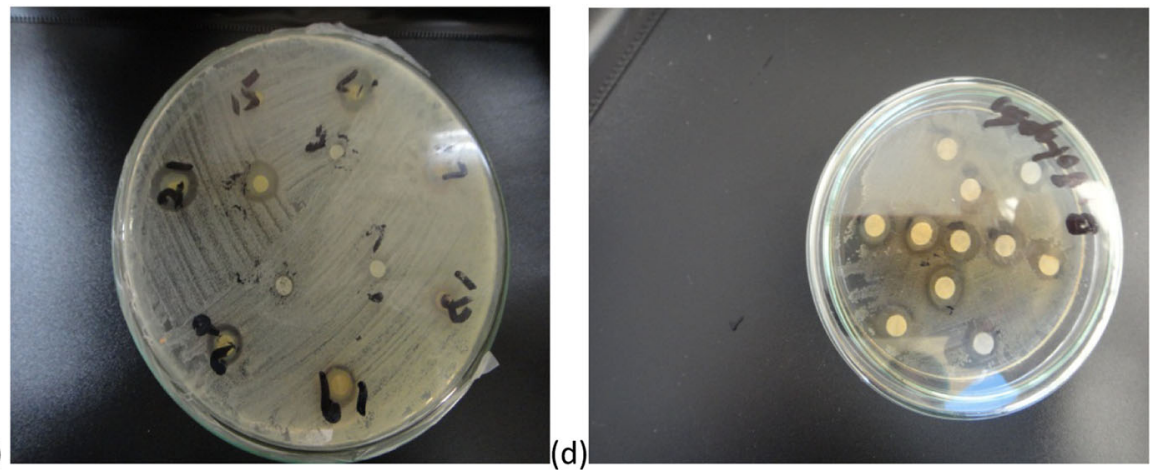

Fig. 5 Antibacterial activity images of A. jacquemontii extracts against a M. lutus $\mathbf{b}$ E. aerogens $\mathbf{c} S$. aureus $\mathbf{d} B$. bronchiseptica

properties and these activities might be related to their antioxidant activities [21]. The biochemical processes inside the cell produce singlet oxygen and free radical which are lethal to the cell. Such compounds save the cells from these threats [22].

A single assay cannot fully predict the rationality behind antioxidant and radical scavenging activities. Therefore multiple assays are employed that cumulatively describe potential of plant extract as antioxidant. The antioxidant activities of extracts were evaluated using $\mathrm{DPPH}$ free radical scavenging assay, total reducing power and total antioxidant capacity assays. The reported DPPH quenching potential of EtOH extract of $A$. jaquamontii was significantly $(P<0.05)$ higher than reported earlier [7, 10]. Other extracts also showed significant DPPH based free radical scavenging activity. However the activity decreased as non-polar solvent was mixed with polar one. A positive correlation was confirmed between TPC, TFC and DPPH scavenging potential of $\mathrm{MeOH}$ and $\mathrm{EtOH}$ extracts of $A$. jaquamontii which is consistent with previously documented positive connectivity between TPC, TFC and quenching potential. DPPH is nitrogen centered free radical that becomes a stable diamagnetic molecule upon acceptance of an electron or hydrogen radical by donor antioxidant which can be quantitatively measured by changes in absorbance. Reactive oxygen species (ROS) are generated mostly as by-products during mitochondrial electron transport and other metabolic reactions. In addition, ROS are formed as necessary intermediates of metal catalyzed oxidation reactions. These free radicals attack not only nucleic acid bases but also deoxyribosyl backbone of DNA causing genotoxicity and ultimately mutations [9, 23]. Innumerable phytoconstituents (Antioxidants) both non enzymatic and enzymatic perform their part in the blockade by means of scavenging or prevention of generation of ROS. Antioxidant activity determined in DPPH and NBT assays showed $64.16 \pm 0.19 \%$ and $62.16 \pm 0.17 \%$, respectively by $A$. jaquamontii extract.

The phosphomolybdenum based total antioxidant capacity of the extracts involves the reduction of Mo (VI) to Mo $(\mathrm{V})$ and subsequent formation of phosphomolybdate complex. The total antioxidant capacity of the extracts attributes to the total phenolic and flavonoid contents $[24,25]$. Phenolic components, such as phenolic acids or phenolic diterpenes, show promising contributors towards antioxidant potential in various medicinal plants. The results strongly correlate the literature where highest antioxidant activities as well as elevated phenolics and flavonoids have been observed in polar extracts including methanol and ethanol. Therefore it can be suggested that active compounds having antioxidant activities are quite polar in nature. Another mode of reduction of free radicals is chelation of metal ions with 


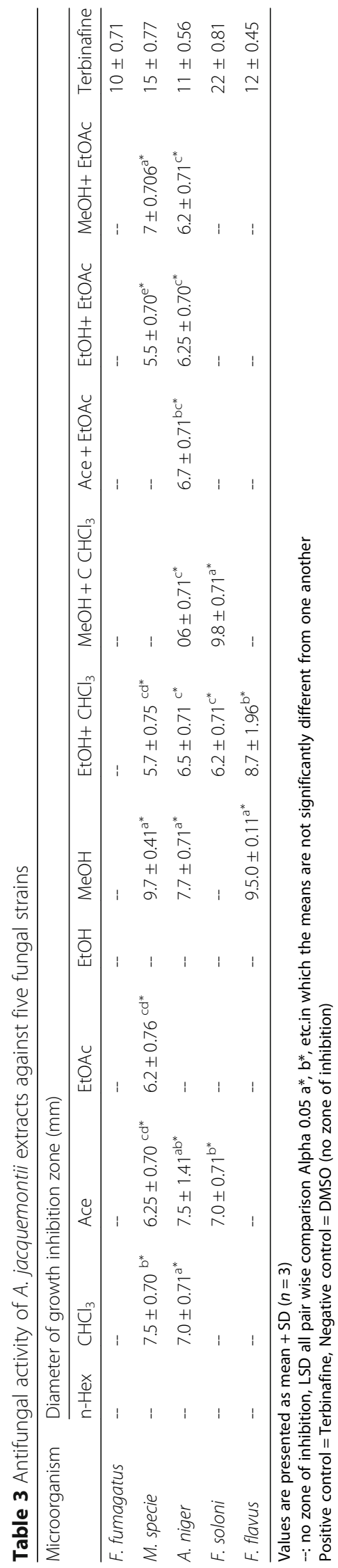


(a)

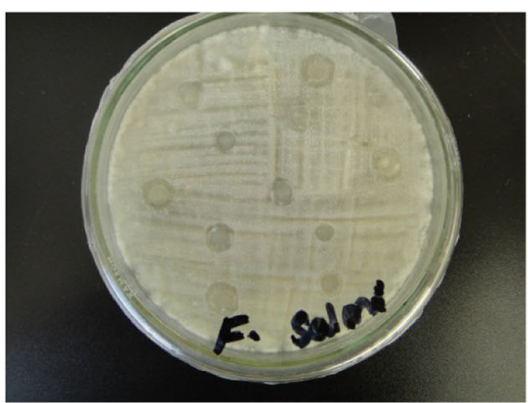

(c)

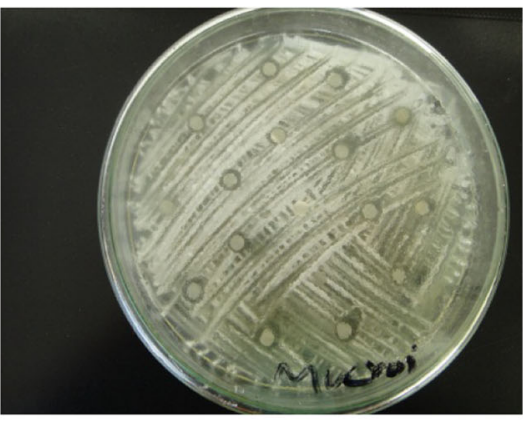

(b)

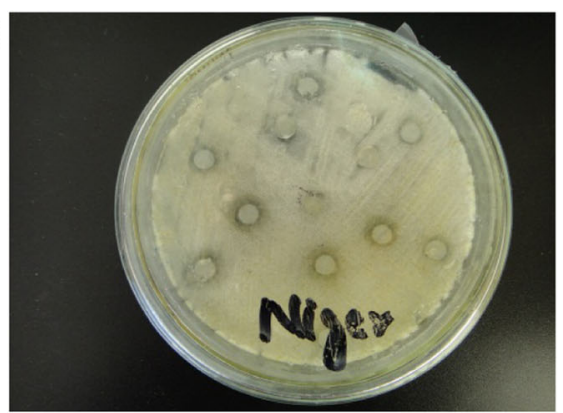

(d)

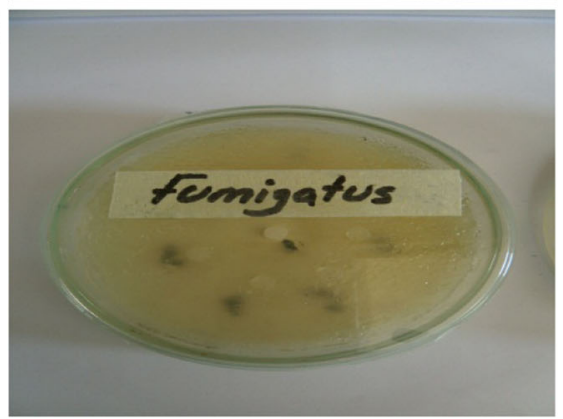

Fig. 6 Antifungal activity images of A. jacquemontii extracts against a F. soloni b A. niger c M. specie d F. fumagatus

chelating agents. The transition metal ion $\mathrm{Fe}^{2+}$ possesses the ability to reduce the formation of free radicals by gain or loss of electrons. The compounds capable of reducing ferric $\left(\mathrm{Fe}^{3+}\right)$ to ferrous $\left(\mathrm{Fe}^{2+}\right)$ depict their reducing power potential which can be observed by the formation of prussian blue-colored complex when $\mathrm{FeCl}_{3}$ is added in reaction mixture [2]. Higher absorbance signifies higher reduction potential [26]. The methanol extract of leaves of $A$. jaquamontii have shown $58 \%$ at $100 \mu \mathrm{g} / \mathrm{mL}$ chelating efficiency and polar fractions demonstrated more antioxidant capacity than other fractions [27].

Brine shrimp assay is used to determine cytotoxic activity of sample [28]. This assay has been widely used as prescreening test i.e. antimicrobial, antitumor, antimalarial, insecticidal, etc. Mortality rate of brine shrimps decreased with the concentration of the extract and degree of lethality was perceived to be concentration dependent. The larvicidal property of $n-H e x$ extract of A. jaquamontii might be attributed to the presence of

Table 4 Cytotoxic potential of A. jacquemontii extracts against DU-145 prostate cancer, HL-60 human leukemia cell lines

\begin{tabular}{|c|c|c|c|c|}
\hline \multirow[t]{2}{*}{ Sample code } & \multicolumn{2}{|l|}{ DU-145 } & \multicolumn{2}{|l|}{$\mathrm{HL}-60$} \\
\hline & $\%$ survival at $20 \mu \mathrm{g} / \mathrm{mL}$ & $\mathrm{ED}_{50} \mathrm{\mu g} / \mathrm{mL}$ & $\%$ survival at $20 \mu \mathrm{g} / \mathrm{mL}$ & $\mathrm{ED}_{50} \mu \mathrm{g} / \mathrm{mL}$ \\
\hline n-Hex & $98.2 \pm 2.1$ & 45.11 & $92.6 \pm 0.8$ & 55.2 \\
\hline $\mathrm{CHCl}_{3}$ & $68.7 \pm 1.5$ & N/A & $52.8 \pm 1.7$ & N/A \\
\hline Ace & $85.3 \pm 0.8$ & N/A & $58.1 \pm 0.6$ & N/A \\
\hline EtOAc & $88.2 \pm 1.9$ & 52.2 & $50.6 \pm 1.2$ & N/A \\
\hline EtOH & $45 \pm 0.5$ & N/A & $66.2 \pm 1.4$ & N/A \\
\hline $\mathrm{MeOH}$ & $89.4 \pm 1.5$ & 66.24 & $86.7 \pm 0.8$ & 65.3 \\
\hline $\mathrm{EtOH}+\mathrm{CHCl}_{3}$ & $75.6 \pm 1.6$ & N/A & $54.2 \pm 0.9$ & N/A \\
\hline $\mathrm{MeOH}+\mathrm{CHCl}_{3}$ & $66.3 \pm 0.8$ & N/A & $71.4 \pm 0.3$ & N/A \\
\hline Ace + EtOAc & $45.6 \pm 1.7$ & N/A & $25.7 \pm 1.4$ & N/A \\
\hline $\mathrm{EtOH}+\mathrm{EtOAc}$ & $23.2 \pm 0.7$ & N/A & $60.7 \pm 0.8$ & N/A \\
\hline $\mathrm{MeOH}+\mathrm{EtOAC}$ & $22.7 \pm 1.4$ & N/A & $54.4 \pm 0.7$ & N/A \\
\hline
\end{tabular}

All data means showed in triplicate. \pm means standard error

ED $50=$ concentration at $50 \%$ inhibition

Taxol used as a positive control

$N / A$ not active 
some cytotoxic constituents which require bioactivity guided isolation and assessment against further cancer cell lines.

Protein kinase inhibitors depict a distinct class of oncogenic kinase inhibitors. Protein kinases are responsible for the phosphorylation of proteins on serine/ threonine and tyrosine residues which are involved in the major regulatory mechanisms in biological processes including apoptosis, cell proliferation, cell differentiation, and metabolism. Occurrence of genetic alterations in early tumor formation can lead to phosphorylation deregulation associated with these pathways and ultimately procreation of cancer. In this regard researchers around the world have shown interest in the identification of kinase inhibitors [29]. Aerial hyphae formation of Streptomyces sp. requires protein kinase activity and a variety of kinase inhibitors are able to block this process [30]. The kinase inhibitory values, in this study, are lower than the hyphae formation inhibition values $(21 \mathrm{~mm}$ clear zone of inhibition at $80 \mu \mathrm{g} / \mathrm{disc}$ ) exhibited by critinin isolated from soil filamentous fungus Penicillium sp. H9318. It can be inferred that n-Hex extract of $A$. jaquamontii might have potential to bind allosterically with active or inactive site of different kinases and inhibits the progression of cancer. Identification of kinase inhibitors may lead to the development of new anticancer drugs. Deregulation of protein kinases is a key factor that play vital role in the pathogenesis of disease. Protein kinase inhibitors block the aerial hyphae formation of Streptomyces sp. [8, 16, 29].

The worldwide dispersion of leishmaniasis and development of resistance against first line therapy demands new therapies for the eradication of this disease [10]. The antileishmanial potential of $\mathrm{ChCl}_{3}$ and $\mathrm{MeOH}$ extracts ( $\mathrm{LC}_{50} 12.87$ and $13.47 \mu \mathrm{g} / \mathrm{ml}$, respectively) of $A$. jaquamontii was considerably lower $\mathrm{LC}_{50}$ than reported earlier [31]. These results are in agreement with previous studies regarding the use of comparatively polar solvents for better extraction of antimicrobial compounds.

The extracts when analyzed against different strains of bacteria, Gram positive strain appeared more susceptible to the inhibitory effect than Gram negative strains. The presence of an extra covering outside the Gram negative bacteria may resist the drug/extract from being entered into the cell. The results are in good accordance with another study in which $\mathrm{MeOH}$ extract of Arisaema utile showed strong antimicrobial effects against the all tested microorganisms [32]. Distribution of activity in less polar fractions indicates that active compounds of the plant are non polar to slightly polar in nature. The antimicrobial activity might be strictly attributed to the synergistic/antagonistic effect of multiple phytochemicals in the composition of a sample. The current results confirm the presence of highly polar to medium polar compounds in A. jacquemontii, which can be a remarkable source of antibacterial agents. This might be due to distribution of active component in specific extract depending upon its solubility nature. A. jaquamontii antibacterial activity revealed that $\mathrm{n}-\mathrm{Hex}$ and EtOAc soluble fractions significantly inhibited the bacterial growth while other showed moderate activity $(6,33)$ The natural bactericidal agents are considered safer in their usage as compared to synthetic and semi synthetic antimicrobial agents. Similarly results also reinforce the substantiation that $\mathrm{MeOH}$ might be an effective solvent for enhanced and efficient extraction of antimicrobials [33, 34]. Such studies inspired the scientist to identify other bioactive compound through isolation.

According to SRB cytotoxic effects, A. jquamontii is highly active against DU-145, and HL-60 cencer cell lines. n-Hex extract showed higher cytotoxity against both cancer cell lines while other extracts did not show remarkable activity against these cancer cell lines. According to literature lectin, a phytocomponent of $A$. jacquemontii inhibit in vitro cytotoxity against PC-3 as (30\%). While anther species of A. helleborrifolium showed an inhibitory effect of MTP and the cytotoxicity against HOP-62, as (95\%) and HCT-15 as (92\%) [32]. A. jaquamontii extracts have been proven for immune modulating potential by $\mathrm{T}$-cell and $\mathrm{B}$-cell proliferation that is due to decrease in acid phosphatase and alkaline phosphatase activities [27, 35]. The NF- $\mathrm{kB}$ signaling has a potential application for the prevention or treatment of cancer. Mammalian cells express NF-kB that is a key nuclear transcription factor.

\section{Conclusion}

The phytochemical and biological potential of A. jacquemontii tuber extracts prepared in different solvent system indicate that selection of solvent affect on phytochemical and biological activities. Polar solvent extracts might be the potential source of phytochemicals provoking highly significant antioxidant, cytotoxic, anticancer and protein kinases inhibitor. The study also indicates that methanol and ethanol extracts of $A$. jaquemontii tuber have high antioxidant potential and radical scavenging activity. Remarkable cytotoxic and antimicrobial activities were best observed in the $\mathrm{n}$-hexane and methanol extracts, respectively. Notable activity by $n$-hexane extract against DU-145 prostate cancer cell lines and HL-60 human leukemia cancer cell lines highlight that this plant specie has anticancer agents. In conclusion the species of Ariseama possess height cytotoxity against the different cancer cell lines and can be used for chemo preventive agent. Tuber of $A$. jaquamontii may be considered as a rich source of potential secondary metabolites with significant biological activities and act as lead source of potent pharmaceuticals. 


\section{Abbreviations}

DMSO: Dimethyl sulfoxide; DPPH: 2, 2-diphenyl-1-picrylhydrazyl; DU145: Prostate cancer cell lines; FRSA: Free radical scavenging activity; HL60: Human promyelocytic leukemia cell line; $I_{5}$ : $50 \%$ inhibitory concentration; $\mathrm{LC}_{50}$ : Lethal concentration causing $50 \%$ mortality; MIC: Minimum inhibitory concentration; MTP: Mitochondrial transmembrane potential; NF-kB: Nuclear factor kappa-B; SRB: Sulphorhodamine B; TAC: Total antioxidant capacity; TFC: Total flavonoid contents; TPC: Total phenolic contents; TRP: Total reducing power; ZOI: Zone of inhibition

\section{Acknowledgements}

The authors are thankful to Dr. Mir Ajab Khan, Department of Plant sciences, Faculty of biological sciences, Quaid-i-Azam University Islamabad, Pakistan for identifying the plant samples. We thank Dr. LC Chang, University of Hawaii at Hilo 96720, HI USA for technical support in the establishment of protein kinase inhibition assay.

\section{Authors' contributions}

ST executed all experimental work and compiled the data. MZ helped in manuscript write up and execution of experiments. EJCdB, MZ and RB made substantial contribution in biological evaluation of samples and revision of manuscript. RA, QW, SH and MMG contributed in study design, supervised the execution of experiments and revised the manuscript. All authors read and approved the final manuscript.

\section{Funding}

No funding was received for this research work.

\section{Availability of data and materials}

The datasets supporting the conclusions of this article are included within the article.

\section{Ethics approval and consent to participate}

The manuscript does not contain any data regarding human or animal objects so no need of approval from ethical committee and consent from participants.

\section{Consent for publication}

Not Applicable

\section{Competing interests}

The authors declare that they have no competing interests.

\section{Author details}

${ }^{1}$ NUTECH School of Applied Sciences and Humanities, National University of Technology (NUTECH), Islamabad, Pakistan. '2Department of Biotechnology, Quaid-I-Azam University, Islamabad 45320, Pakistan. ${ }^{3}$ Division of Pharmacy Practice Science and Division of Medicinal Chemistry and Pharmacognosy, College of Pharmacy, The Ohio State University, Columbus, OH, USA.

Received: 15 March 2019 Accepted: 30 August 2019

Published online: 14 September 2019

\section{References}

1. Tabassum S, Ahmed M, Mirza B, Naeem M, Zia M, Shanwari ZK, Khan GM. Appraisal of phytochemical and in vitro biological attributes of an unexplored folklore: Rhus Punjabensis Stewart. BMC Complement Altern Med. 2017 Dec;17(1):146.

2. Elisha IL, Botha FS, McGaw L, Eloff JN. The antibacterial activity of extracts of nine plant species with good activity against Escherichia coli against five other bacteria and cytotoxicity of extracts. BMC Complement Altern Med. 2017;17(1):133.

3. Ayaz M, et al. Cytotoxicity and molecular docking studies on Phytosterols isolated from Polygonum hydropiper L. Steroids. 2019;141:30-5.

4. Imran $\mathrm{M}$, et al. Anticholinesterase and antioxidant potentials of Nonea micrantha Bioss. \& Reut along with GC-MS analysis. BMC Complement Altern Med. 2017;17(1):499.

5. Zohra T, Ovais M, Khalil AT, Qasim M, Ayaz M, Shinwari ZK. Extraction optimization, total phenolic, flavonoid contents, HPLC-DAD analysis and diverse pharmacological evaluations of Dysphania ambrosioides (L.) Mosyakin \& Clemants. Nat Prod Res. 2019;33(1):136-42.
6. Baba SA, Malik SA. Determination of total phenolic and flavonoid content, antimicrobial and antioxidant activity of a root extract of Arisaema jacquemontii Blume. J Taibah Univ Sci. 2015;9(4):449-54.

7. Jeelani $\mathrm{S}$, Khuroo MA, Razadan TK. New triterpenoids from Arisaema jacquemontii. J Asian Nat Prod Res. 2010;12(2):157-61.

8. Kaur $\mathrm{M}$, et al. A tuber lectin from Arisaema jacquemontii Blume with antiinsect and anti-proliferative properties. BMB Rep. 2006;39(4):432-40.

9. Verma H, Lal VK, Pant KK, Soni N. A review on Arisaema jacquemontii. J Pharm Res. 2012;5:1480-2.

10. Tanveer M, Habib-Ur-Rehman MM, Choudhary M. Immunomodulatory, antileishmanial and phytotoxicity of Arisaema Jacquemontii Blume plant extracts. Arch Appl Sci Res. 2014;6(5):12-7.

11. Ovais M, Khalil A, Ayaz M, Ahmad I, Nethi S, Mukherjee S. Biosynthesis of metal nanoparticles via microbial enzymes: a mechanistic approach. Int J Mol Sci. 2018;19(12):4100.

12. Zahra SS, Ahmed M, Qasim M, Gul B, Zia M, Mirza B, Haq IU. Polarity based characterization of biologically active extracts of Ajuga bracteosa Wall. ex Benth. and RP-HPLC analysis. BMC Complement Altern Med. 2017;17(1):443.

13. Rosen M. Delivery system handbook for personal care and cosmetic products: technology, applications and formulations: William Andrew; 2005. ebookISBN: 9780815516828.

14. Shah SM, Ullah F, Ayaz M, Sadiq A, Hussain S, Shah SA, Nadhman A. $\beta-$ Sitosterol from Ifloga spicata (Forssk.) Sch. Bip. as potential anti-leishmanial agent against leishmania tropica: docking and molecular insights. Steroids. 2019;148:56-62.

15. Naz S, Shams F, Tabassum S, Ashraf M, Zia M. Kinnow peel extract as a reducing and capping agent for the fabrication of silver NPs and their biological applications. IET Nanobiotechnol. 2017;11(8):1040-5.

16. Naz S, Islam M, Tabassum S, Fernandes NF, de Blanco EJC, Zia M. Green synthesis of hematite (a-Fe2O3) nanoparticles using Rhus punjabensis extract and their biomedical prospect in pathogenic diseases and cancer. J Mol Struct. 2019;1185:1-7.

17. Naz S, Tabassum S, Freitas Fernandes N, Mujahid M, Zia M, Carcache de Blanco EJ. Anticancer and antibacterial potential of Rhus punjabensis and CuO nanoparticles. Nat Prod Res. 2018;32:1-6. https://doi.org/10.1086/ 14786419.2018.1495633.

18. Sarwar HS, et al. Mannosylated thiolated polyethylenimine nanoparticles for the enhanced efficacy of antimonial drug against Leishmaniasis. Nanomedicine. 2018;13(1):25-41.

19. Ovais $\mathrm{M}$, et al. Biosynthesized colloidal silver and gold nanoparticles as emerging leishmanicidal agents: an insight. Nanomedicine. 2017;12(24):2807-19.

20. Roshan R, Ahmed S, Hasan MM. Arisaema jacquemontii Blume (Araceae): a review of medicinal uses, phytochemistry and pharmacology. J Pharmacogn Phytochem. 2017;6(6):429-32.

21. Hendra R, Ahmad S, Oskoueian E, Sukari A, Shukor MY. Antioxidant, antiinflammatory and cytotoxicity of Phaleria macrocarpa (Boerl.) Scheff fruit. BMC Complement Altern Med. 2011;11(1):110.

22. Hong SK, Matsumoto A, Horinouchi S, Beppu T. Effects of protein kinase inhibitors on in vitro protein phosphorylation and cellular differentiation of Streptomyces griseus. Mol Gen Genet MGG. 1993;236(2-3):347-54.

23. Gullon B, Eibes G, Moreira MT, Davila I, Labidi J, Gullon P. Antioxidant and antimicrobial activities of extracts obtained from the refining of autohydrolysis liquors of vine shoots. Ind Crop Prod. 2019;107:105-13.

24. Magid AA, Schmitt M, Prin PC, Pasquier L, Voutquenne-Nazabadioko L. In vitro Tyrosinase inhibitory and antioxidant activities of extracts and constituents of Paeonia lactiflora Pall. Flowers. Nat Prod J. 2017;7(3):237-45.

25. Kolár P, Shen JW, Tsuboi A, Ishikawa T. Solvent selection for pharmaceuticals. Fluid Phase Equilib. 2002;194:771-82.

26. Ang AMG, Nalda CMDR, Sabejon SE. Brine shrimp lethality and antioxidant activity of the leaf, rind and seed ethanolic extracts of Durio zibethinus L. Asian J Biol Life Sci. 2018;7(3):105.

27. Sudan R, Bhagat M, Gupta S, Singh J, Koul A. Iron (Fell) chelation, ferric reducing antioxidant power, and immune modulating potential of Arisaema jacquemontii (Himalayan Cobra Lily). Biomed Res Int. 2014;2014:1.

28. Pandey N, Barve D, Prajapati N, Dubey BK. Evaluation of hepatoprotective activity of ethanolic extract of Arisaema leschenaultia Blume tuber in paracetamolinduced hepatotoxicity in Swiss albino mice. Int J Res Pharmaceut Biomed Sci. 2012;3:312-8.

29. Naz S, Kazmi STB, Zia M. CeO2 nanoparticles synthesized through green chemistry are biocompatible: In vitro and in vivo assessment. J Biochem Mol Toxicol. 2019;33:e22291. 
30. Zhao FW, Luo M, Wang YH, Li ML, Tang GH, Long CL. A piperidine alkaloid and limonoids from Arisaema decipiens, a traditional antitumor herb used by the Dong people. Arch Pharm Res. 2010;33(11):1735-9.

31. Hamid R, Masood A, Wani IH, Rafiq S. Lectins: proteins with diverse applications. J Appl Pharm Sci. 2013;3(4.1):93-103.

32. Ma G, Khan SI, Jacob MR, Tekwani BL, Li Z, Pasco DS, Walker LA, Khan IA. Antimicrobial and antileishmanial activities of hypocrellins A and B. Antimicrob Agents Chemother. 2004;48(11):4450-2.

33. Iqbal M, Bakht J, Shafi M. Phytochemical screening and antibacterial activity of different solvent extracted samples of Arisaema jacquemontii. Pak J Pharm Sci. 2018:31(1):75.

34. Valko M, Izakovic M, Mazur M, Rhodes CJ, Telser J. Role of oxygen radicals in DNA damage and cancer incidence. Mol Cell Biochem. 2004;266(1-2):37-56.

35. Kaur M, Singh K, Rup PJ, Kamboj SS, Saxena AK, Sharma M, Bhagat M, Sood SK, Singh J. A tuber lectin from Arisaema jacquemontii Blume with antiinsect and anti-proliferative properties. BMB Rep. 2066;39(4):432-40.

\section{Publisher's Note}

Springer Nature remains neutral with regard to jurisdictional claims in published maps and institutional affiliations.

Ready to submit your research? Choose BMC and benefit from:

- fast, convenient online submission

- thorough peer review by experienced researchers in your field

- rapid publication on acceptance

- support for research data, including large and complex data types

- gold Open Access which fosters wider collaboration and increased citations

- maximum visibility for your research: over $100 \mathrm{M}$ website views per year

At $\mathrm{BMC}$, research is always in progress.

Learn more biomedcentral.com/submissions 